\title{
Corrosion Behaviors of Hydroxyapatite Coated by Electrodeposition Method of Ti6Al4V, Ti and AISI 316L SS Substrates
}

\author{
Aysel Büyüksa ğiş*, ${ }^{*}$, Emine Bulut ${ }^{1}$, Yusuf Kayalı ${ }^{2}$ \\ ${ }^{1}$ Afyon Kocatepe University, Science and Literatur Faculty, Afyonkarahisar, Turkey \\ ${ }^{2}$ Afyon Kocatepe University, Technical Education Faculty, Afyonkarahisar, Turkey \\ e-mail : ayselbuyuksagis@hotmail.com,absagis@aku.edu.tr \\ Received May 07, 2012
}

\begin{abstract}
Electrodeposition method was used to obtain hydroxyapatite (HAP) coatings on Ti6Al4V, Ti and AISI 316L SS substrates. Electrodeposition solution is prepared as $\mathrm{Ca}\left(\mathrm{NO}_{3}\right)_{2} \cdot 4 \mathrm{H}_{2} \mathrm{O}$ and $\left(\mathrm{NH}_{4}\right) \mathrm{H}_{2} \mathrm{PO}_{4}$. Additionally, three different pretreatment surface operations (PTSO) ( $\mathrm{HNO}_{3}$, anodic polarization, baseacid) were applied to the substrates. Surface morphology of HAP coated substrates were characterized by SEM, EDS, XRD. HAP coatings were successfully deposited on Ti6Al4V, AISI 316L SS and Ti substrates Corrosion behavior of uncoated and HAP coated substrates were examined in the Ringer and $0.9 \% \mathrm{NaCl}$ solutions. The XRD, SEM-EDS results supported that HAP formation on the substrates. $i_{\text {cor }}$ values for all three HAP coated substrates are higher than uncoated substrates This showed that, electrochemical deposition HAP coating could not prevent the corrosion. The lowest corrosion rates were founded $\mathrm{HNO}_{3} \mathrm{PTSO}$ substrates.
\end{abstract}

DOI: $10.1134 / \mathrm{S} 207020511306018 \mathrm{X}$

\section{INTRODUCTION}

In the past 20 years, titanium and its alloys have been 1 accomplished used as odontic and orthopedic biomaterials because of their good mechanical properties, corrosion resistance and biocompatibility with alive tissue after implantation into the bone. However, being bioinert metallic materials, they cannot connection to living bone directly after implantation into a host body. Therefore, various surface modifications have been tested to improve the bioactive bone-bonding ability of biomaterials [1-4]. Hydroxyapatite (HAP) can bond to living bony tissues and, it is being widely used in clinical applications. One major application of HAP is to serve as a cover material for titanium or other metals used in biomaterials. In this case, the biocompatibility of biomaterials is assured by HAP, while the mechanical properties are provided by the metal substrate [5-10]. Typical coating methodologies like ion beam assisted deposition [11-15], plasma spray deposition [16-20], pulsed laser deposition [21-27], magnetron sputtering [28-32], sol-gel derived coatings [33-40], biomimetik [41-45], electrodeposition [6, 39, 46-65], electrocemical cathodic deposition [66-68], pulse electrodeposition [69-70] are extensively studied. The process of electrodeposition has been described to be influenced by the electrolyte composition, process temperature, hydrodynamic flow, deposition time and current density [47] HAP increases with increasing electrolyte tem-

\footnotetext{
${ }^{1}$ The article is published in the original.
}

perature [6]. Electrodeposition is an alternative technique but this also has disadvantages, mainly the crystallinity of the deposited hydroxyapatite and its adhesion to the substrate [66]. Electrodeposition HAP method is generally produced brushite (dicalcium phosphate dihydrate $\mathrm{CaHPO}_{4} \cdot 2 \mathrm{H}_{2} \mathrm{O}$ ). Coating thickness and weight gain are increased and the morphology changed with increasing deposition current density [46]. Pulsed electrodeposition without $\mathrm{H}_{2} \mathrm{O}_{2}$ into electrolyte followed by heat treatment favoured coatings made of two phases which are stoichiometric hydroxyapatite (HAP) and $\beta$-tricalcium phosphate $(\beta$-TCP) [70]. The hybrid coating tantalum oxide/organophosphonic acids/molecular layer is shown to be promising for orthopaedic biomaterials [71].

\section{MATERIAL AND METHODS}

\subsection{The Preparing Substrates}

Surface condition of the substrates a major role in the development of electrochemical deposition HAP coating and their corrosion resistance. The surface roughness of the substrate is particularly important not only because a rough surface can provide increased wettability of the HAP precursor solution on the substrate, but also because mechanical interlocking between the HAP-coated layer and substrate may be enhanced to avoid the failure of the coated HAP layer under shear stress [72]. Before coating, the substrates were polished and cleaned by using Bandelin ultrasonic bath for 
15 minutes in order acetone, alcohol, bidistilleted water $30^{\circ} \mathrm{C}$. Then, they were dried at $40^{\circ} \mathrm{C}$ for one hour in oven. So, they were made ready for pretreatment surface operations (PTSO).

\subsection{Pretreatment Surface Operations of Substrates (PTSO)}

The increase in surface roughness of the coating provides the nucleation sites with lower interface energy for bone-like apatite to anchor [5]. Three different pretreatment surface operations are applied to substrates. These are summarized as follows:

a) Acid-base PTSO: The substrates are soaked in 5 2 moldm $^{-3} \mathrm{NaOH}$ solution for 12 hours on $60^{\circ} \mathrm{C}$ and then on $25^{\circ} \mathrm{C}$ for 12 hours. Then, they are washed at the ultrasonic bath for 15 minutes by bidistilleted water for two times and dried in the oven on $40^{\circ} \mathrm{C}$ for one hour. It can be seen that a porous network structure was formed on the surface of substrates with the $\mathrm{NaOH}$ treatment $[6,73,74]$. The precursors reported that pre-calcification improved bioactivity as expressed by an increase in precipitation of apatite, and alkali-treatment process formed the bioactive $\mathrm{Ti}-\mathrm{OH}$ film on titanium surface [63]. This process resulted in a vertical growth of the hydroxyapatite crystals and increased the bond strength of the coating [52]. Subsequently, the substrates are 2 soaked in $60^{\circ} \mathrm{C}$ at 1 moldm ${ }^{-3} \mathrm{HCl}$ for 12 hours and then 12 hours at room temperature. Following acid treatment, the substrates rewashed with running bidistilled water and dried at $40^{\circ} \mathrm{C}$ for one hour. The $\mathrm{HCl}$ pretreatment inhibits the negative effect of titanium processing on titanate hydrogel layer formation and the subsequent HAP precipitation is steady and reproducible. For a bioactive material, the ability of the surface to induce apatite precipitation as well as the rate of apatite formation is very important [74].

b) Anodic Polarization PTSO: Anodic polarization is 2 done 1 moldm $^{-3}$ HCI solution. It is confirmed that 2 optimum time is treated 300 seconds in 1 moldm $^{-3} \mathrm{HCl}$ solution and potential value is determined as $5 \mathrm{~V}$.

c) $\mathrm{HNO}_{3}$ PTSO: Substrates are grounded from rough emery paper to fine emery paper (120-1200 grit paper) and are washed bidistilled water by ultrasonic bath. Then substrates are soaked for 20 minutes with technical $\mathrm{HNO}_{3}$ and following acid treatment, the substrates are washed with running bidistilled water and dried at $40^{\circ} \mathrm{C}$ for one hour. The substrates are cleaned in Bandelin ultrasonic bath for 15 minutes in order acetone, alcohol, bidistilleted water $30^{\circ} \mathrm{C}$. Then, they are dried at $40^{\circ} \mathrm{C}$ for one hour in oven. Surface of substrates are made porous for HAP coating. Substrates are hidden in desiccator after put in locked plastic bags [75-76].

\subsection{HAP Coating by Electrodeposition Method}

Electrodeposition solution is prepared as 220.042 moldm $^{-3} \mathrm{Ca}\left(\mathrm{NO}_{3}\right)_{2} \cdot 4 \mathrm{H}_{2} \mathrm{O}, 0.025$ moldm $^{-3}$
$\left(\mathrm{NH}_{4}\right) \mathrm{H}_{2} \mathrm{PO}_{4}, 0.15$ moldm $^{-3} \mathrm{NaNO}_{3}, 10 \mathrm{~cm}^{3} \mathrm{dm}^{-3} 2$ $\mathrm{H}_{2} \mathrm{O}_{2}$. $\mathrm{NaNO}_{3}$ was used to increase the ionic conductivity of the electrolyte [63, 77]. When high voltage is applied to the system during electrochemical deposition $\mathrm{H}_{2}$ formation accelerates. Formed $\mathrm{H}_{2}$ increases the porosity of the coating and prevents hydroxyapatite from sticking to the surface. During electrodeposition, in order to prevent hydrogen output from deteriorating the coating $\mathrm{H}_{2} \mathrm{O}_{2}$ is added to the coating solution before electrodeposition. On the other hand the addition of $\mathrm{H}_{2} \mathrm{O}_{2}$ into electrolyte led to adherent and uniform coatings mainly made of stoichiometric hydroxyapatite (HAP) [56, 63, 70]. HAP coating is produced in 1 hour under 3 V voltage by using a DC power source. Nitrogen gas was passed through the system for 45 minutes before coating. The reason for passing nitrogen gas through the system is to decrease the amount of $\mathrm{CO}_{2}$, which is present in the coating solution in dissolved form, and to prevent $\mathrm{CaCO}_{3}$ deposition [66]. The $\mathrm{pH}$ value of electrodeposition solution was set to 5.5 at $85^{\circ} \mathrm{C}$ by using tris (hydroxymethyl) aminomethane (TRIS) and $\mathrm{HCl}$. The coating was formed at $85^{\circ} \mathrm{C}$ by using thermostat circulating water bath. Pt plate electrode was used as anode. Ti6Al4V, Ti and AISI 316L SS substrates, surface of which would be coated with hydroxyapatite, were used as cathode. The distance between anode and cathode was set to $5 \mathrm{~mm}$ and the solution was constantly stirred during coating. There are two effects of stirring the solution; first it draws away $\mathrm{H}_{2}$ gas bubbles due to centrifuge effect. Second, it accelerates the mass transportation rate of both reactants and products to the electrode surface [66].

HAP coated samples were dried in oven at $60^{\circ} \mathrm{C}$ for 1 hour. Sintering process; the temperature was set to $400^{\circ} \mathrm{C}$ after the samples have been put into muffled furnace. It was kept still for 10 minutes when the temperature reached $400^{\circ} \mathrm{C}$. Then the furnace was turned off after waiting for 10 minutes by each $100^{\circ} \mathrm{C}$ increase and for 30 minutes at $850^{\circ} \mathrm{C}$, and the substrates were taken from the muffled furnace one day later. The thickness of the HAP coatings were measured using EBAN 2000 MK2 (0-1000 $\mu \mathrm{m})$ device.

\subsection{Electrochemical Measurements and Surface Morphology Studies}

Chemical reagents are used Merck. All the electrochemical measurements were performed using Reference 600 potentiostate/galvanostate/ZRA system (USA) supported by echem analyst soft programme. In these measurements, AISI 316L SS, Ti6Al4V alloy and Ti substrates were used as the working electrode while platinum electrode was used as the counter electrode, and saturated calomel electrode (SCE) as the reference electrode. Electrochemical evaluations involving potentiodynamic polarization studies were performed in the Ringer's solution $\left(\mathrm{NaCl} 8.6 \mathrm{gL}^{-1}, \mathrm{CaCl}_{2} \cdot 2 \mathrm{H}_{2} \mathrm{O}\right.$ $0.66 \mathrm{gL}^{-1}$ and $\left.\mathrm{KCl} 0.6 \mathrm{gL}^{-1}\right)$ and $\% 0.9 \mathrm{NaCl}$ solution. All the potential values in the text are relative to the 
(a)

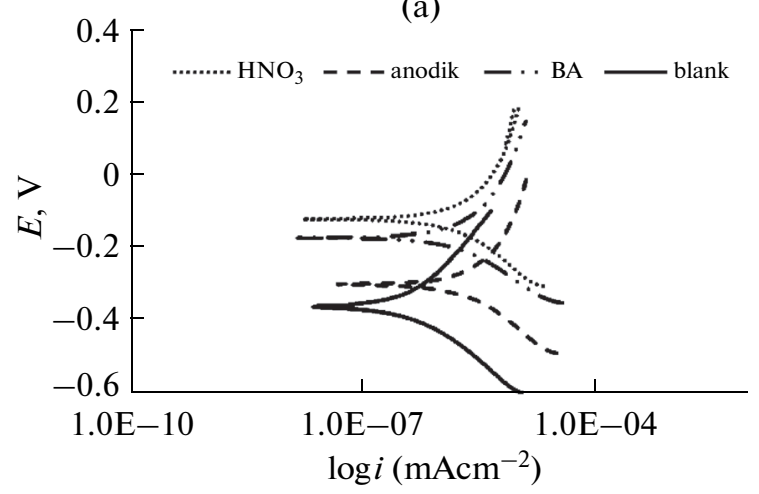

(b)

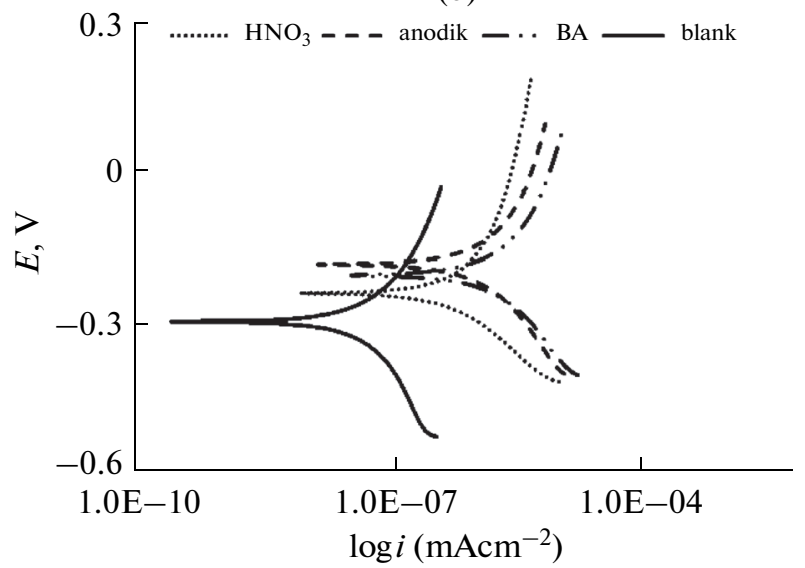

(c)

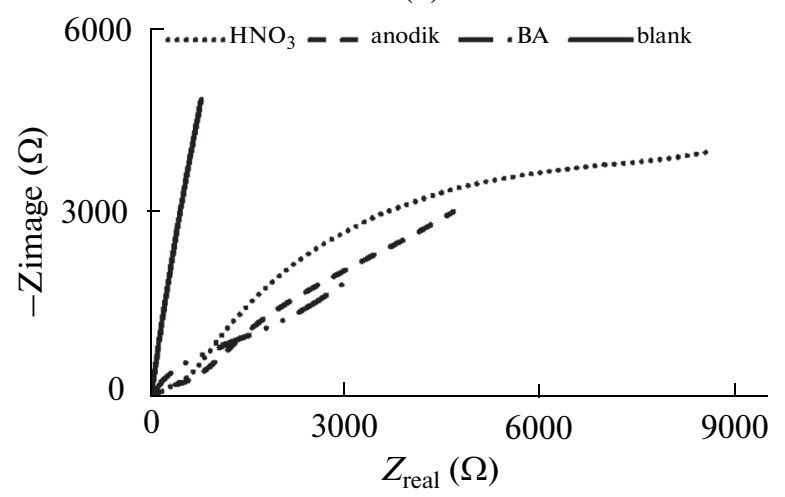

(d)

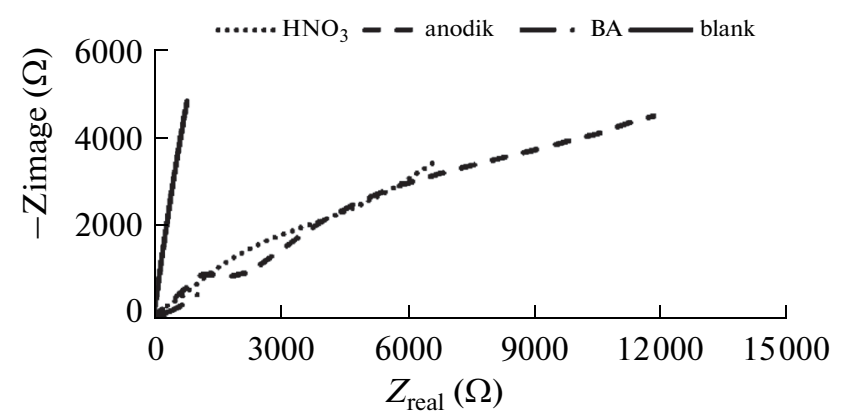

Fig. 1. Electrochemical plots for Ti6Al4V alloy after electrodeposition HA coating

SCE. In order to test the reproducibility of the results, the experiments were performed in triplicate.

After electrochemical measurements, surface images are taken from by LEO 1430 VP SEM microscope. EDS spectrums are also had over same samples. $\mathrm{XRD}$ is used to determine structure of HAP on substrates.

\section{EXPERIMENTAL RESULTS AND DISCUSSIONS}

\subsection{Electrochemical Experimental Results after Electrodeposition HAP Coating}

Electrochemical curves obtained from Ringer and $0.9 \% \mathrm{NaCl}$ solutions were given Fig. 1 for uncoated and HAP coated Ti6Al4V alloy substrates. Corrosion characteristics for Ti6Al4V alloy substrates in Ringer and $0.9 \% \mathrm{NaCl}$ solutions were given in Table 1 . Table 1 and Fig. 1 present, the corrosion rate of HAP coated substrates with by using electrodeposition method has increased. $E_{\text {cor }}$ values have shifted to more negative potentials with in Ringer and $0.9 \% \mathrm{NaCl}$ solutions. This showed that, electrochemical deposition HAP coating could not prevent the corrosion. When polarization resistance (Table 1) values were examined, polarization resistance of electrodeposition HAP coated samples were decreased.

The lowest corrosion rate was calculated $\mathrm{HNO}_{3}$ PTSO Ti6Al4V substrate in Ringer solution as $0.87 \mu \mathrm{Acm}^{-2}$. Electrochemical curves obtained from Ringer and $0.9 \% \mathrm{NaCl}$ solutions were given Fig. 2 for Ti substrates. The corrosion characteristics of Ti substrates are given in Table 2. $i_{\text {cor }}$ values are lower when compared to Ti6Al4V alloy. $E_{\text {cor }}$ values have shifted to more positive potentials when compared to Ringer solution (Table 2 and Fig. 2). It showed variety in $0.9 \% \mathrm{NaCl}$ solution.

In Table 2 and Fig. 2 the lowest corrosion rate can be seen in $\mathrm{HNO}_{3}$ PTSO Ti substrate in Ringer solution. In their studies, Ban and Hasegawa [78] reported that hydrothermal electrochemical deposition consists of two steps; nucleation and crystal growth. It is assumed that the first step of electrochemical deposition starts with heterogeneous nucleation. Deposition increases proportionally with increased temperature. Electrochemical curves obtained for AISI 316L SS from Ringer and $0.9 \% \mathrm{NaCl}$ solutions were given Fig. 3. The corrosion characteristics of AISI 316L SS are given in Table 3.

When Table 3 and Fig. 3 are examined there is a decrease in the corrosion rate of $\mathrm{HNO}_{3}$ PTSO AISI 
Table 1. Corrosion characteristics of Ti6Al4V alloy after electrodeposition HA coating

\begin{tabular}{|c|c|c|c|c|c|c|c|c|}
\hline & Ti6Al4V alloy & PTSO & $-E_{\mathrm{cor}}(\mathrm{mV})$ & $\begin{array}{c}\beta_{\mathrm{a}} \times 10^{3} \\
(\mathrm{~V} / \text { decade })\end{array}$ & $\begin{array}{c}\beta_{\mathrm{c}} \times 10^{3} \\
(\mathrm{~V} / \text { decade })\end{array}$ & $\begin{array}{c}i_{\mathrm{cor}} \\
\left(\mu \mathrm{Am}^{-2}\right)\end{array}$ & $\begin{array}{c}\text { Corr.rate } \\
\text { (mpy) }\end{array}$ & $R_{p}(\mathrm{k} \Omega)$ \\
\hline \multirow[t]{2}{*}{ Uncoated } & Ringer'ssolution & - & 276 & 364 & 600 & 0.097 & 0.033 & 299 \\
\hline & $\% 0.9 \mathrm{NaCl}$ solution & - & 351 & 410 & $5.75 \times 10^{3}$ & 0.172 & 0.060 & 359 \\
\hline \multirow[t]{6}{*}{ Coated } & Ringer'ssolution & $\mathrm{HNO}_{3}$ & 220 & 297 & 166 & 0.87 & 0.10 & 117 \\
\hline & & anodic & 211 & 307 & 271 & 4.41 & 1.53 & 12 \\
\hline & & BA & 265 & 586 & 232 & 2.36 & 0.82 & 15.31 \\
\hline & $\% 0.9 \mathrm{NaCl}$ solution & $\mathrm{HNO}_{3}$ & 193 & 398 & 189 & 2.35 & 0.27 & 27.84 \\
\hline & & anodic & 237 & 697 & 380 & 3.34 & 1.13 & 21.68 \\
\hline & & BA & 320 & 1095 & 446 & 1.26 & 0.44 & 986 \\
\hline
\end{tabular}

316L SS substrate in Ringer solution. \% inhibition value is $53 \%$. There is no inhibition in others. $i_{\text {cor }}$ values have increased. Corrosion has continued on HAP coated surfaces in electrodeposition method.

The following reactions occur on cathode surface during cathodic deposition:

$$
\begin{gathered}
2 \mathrm{H}_{2} \mathrm{O}+2 \rightarrow \mathrm{H}_{2}+2 \mathrm{OH}^{-} \\
\mathrm{O}_{2}+\mathrm{H}_{3} \mathrm{O}^{+}+4 \rightarrow 3 \mathrm{OH}^{-} \\
\mathrm{NO}_{3}^{-}+\mathrm{H}_{2} \mathrm{O}+2 \rightarrow \mathrm{NO}_{2}^{-}+2 \mathrm{OH}^{-}
\end{gathered}
$$
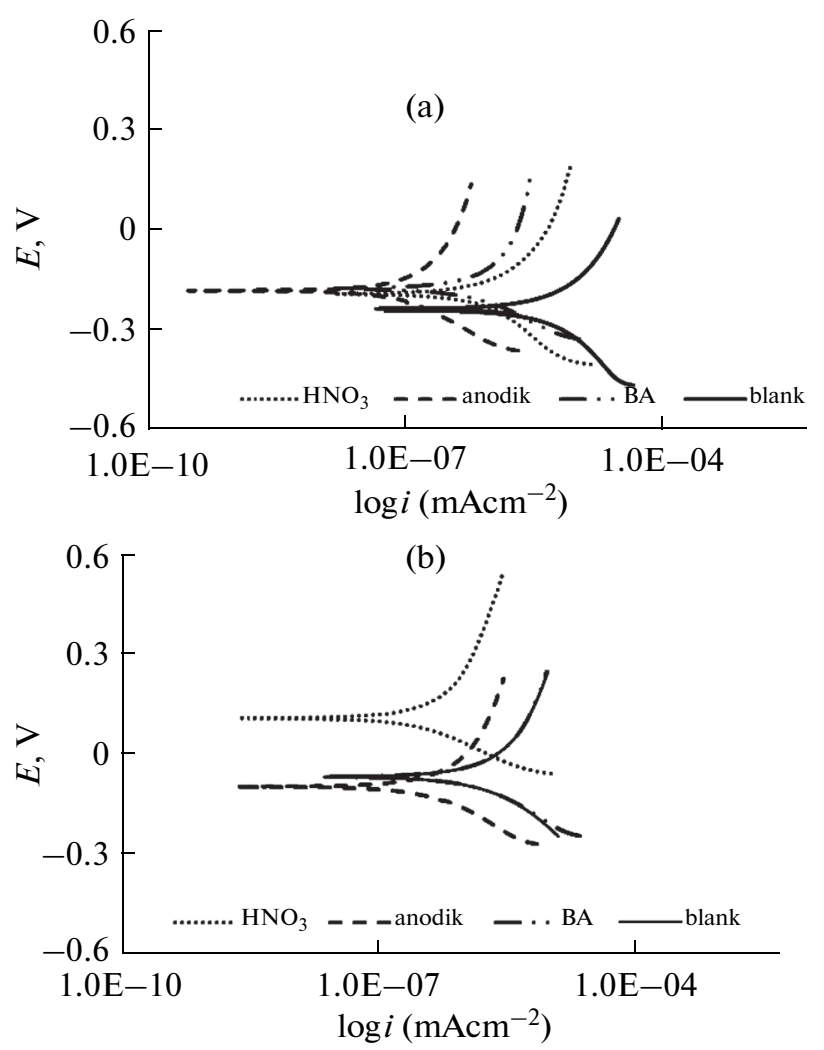

$$
\begin{gathered}
2 \mathrm{H}_{2} \mathrm{PO}_{4}^{-}+2 \mathrm{H}_{2} \mathrm{O}+2 \rightarrow 2 \mathrm{H}_{2} \mathrm{PO}_{3}^{-}+4 \mathrm{OH}^{-} \\
2 \mathrm{H}_{2} \mathrm{PO}_{4}^{-}+2 \rightarrow 2 \mathrm{H}_{2} \mathrm{PO}_{4}^{-}+\mathrm{H}_{2} \\
2 \mathrm{HPO}_{4}^{2-}+2 \rightarrow 2 \mathrm{PO}_{4}^{3-}+\mathrm{H}_{2}
\end{gathered}
$$

1-4 reactions produce hydroxide which causes $\mathrm{pH}$ increase in diffusion layer on cathode surface. Simultaneously there is an increase in the concentration of phosphate ions ( 5 and 6 reactions). On titanium surface hydroxyl groups makes a chemical bond with calcium

Fig. 2. Electrochemical plots for Ti after electrodeposition HA coating 
Table 2. Corrosion characteristics of Ti after electrodeposition HA coating

\begin{tabular}{|c|c|c|c|c|c|c|c|c|}
\hline & $\mathrm{Ti}$ & PTSO & $-E_{\mathrm{cor}}(\mathrm{mV})$ & $\begin{array}{c}\beta_{\mathrm{a}} \times 10^{3} \\
(\mathrm{~V} / \text { decade })\end{array}$ & $\begin{array}{c}\beta_{\mathrm{c}} \times 10^{3} \\
(\mathrm{~V} / \text { decade })\end{array}$ & $\left(\mu \mathrm{A} \mathrm{cor}^{-2}\right)$ & $\begin{array}{c}\text { Corr.rate } \\
\text { (mpy) }\end{array}$ & $\begin{array}{c}R_{p} \\
(\mathrm{k} \Omega)\end{array}$ \\
\hline \multirow[t]{2}{*}{ Uncoated } & Ringer'ssolution & - & 231 & 80.4 & 29.73 & $15.5 \times 10^{-3}$ & 5.276 & 257 \\
\hline & $\% 0.9 \mathrm{NaCl}$ solution & - & 191 & 296 & 160 & 0.211 & 0.066 & 295.0 \\
\hline \multirow[t]{6}{*}{ Coated } & Ringer'ssolution & $\mathrm{HNO}_{3}$ & 76 & 505 & 189 & 0.184 & 0.06 & 189 \\
\hline & & anodic & 80 & 485 & 250 & 0.767 & 0.26 & 59.21 \\
\hline & & BA & 100 & 832 & 301 & 0.84 & 0.29 & 116.38 \\
\hline & $\% 0.9 \mathrm{NaCl}$ solution & $\mathrm{HNO}_{3}$ & 218 & 778 & 418 & 0.83 & 0.28 & 237.5 \\
\hline & & anodic & 195 & 733 & 243 & 0.46 & 0.15 & 215 \\
\hline & & BA & 128 & 634 & 234 & 0.33 & 0.11 & 156 \\
\hline
\end{tabular}

and phosphate in order to produce HAP coating (reaction 7).

$$
10 \mathrm{Ca}^{2+}+6 \mathrm{PO}_{4}^{3-}+2 \mathrm{OH}^{-} \rightarrow \mathrm{Ca}_{10}\left(\mathrm{PO}_{4}\right)_{6}(\mathrm{OH})_{2}
$$

Deposition of HA occurs in two steps: ation

1) Occurrence of two dimension growth with nucle-

2) Three dimensional occurrence of progressed nucleation
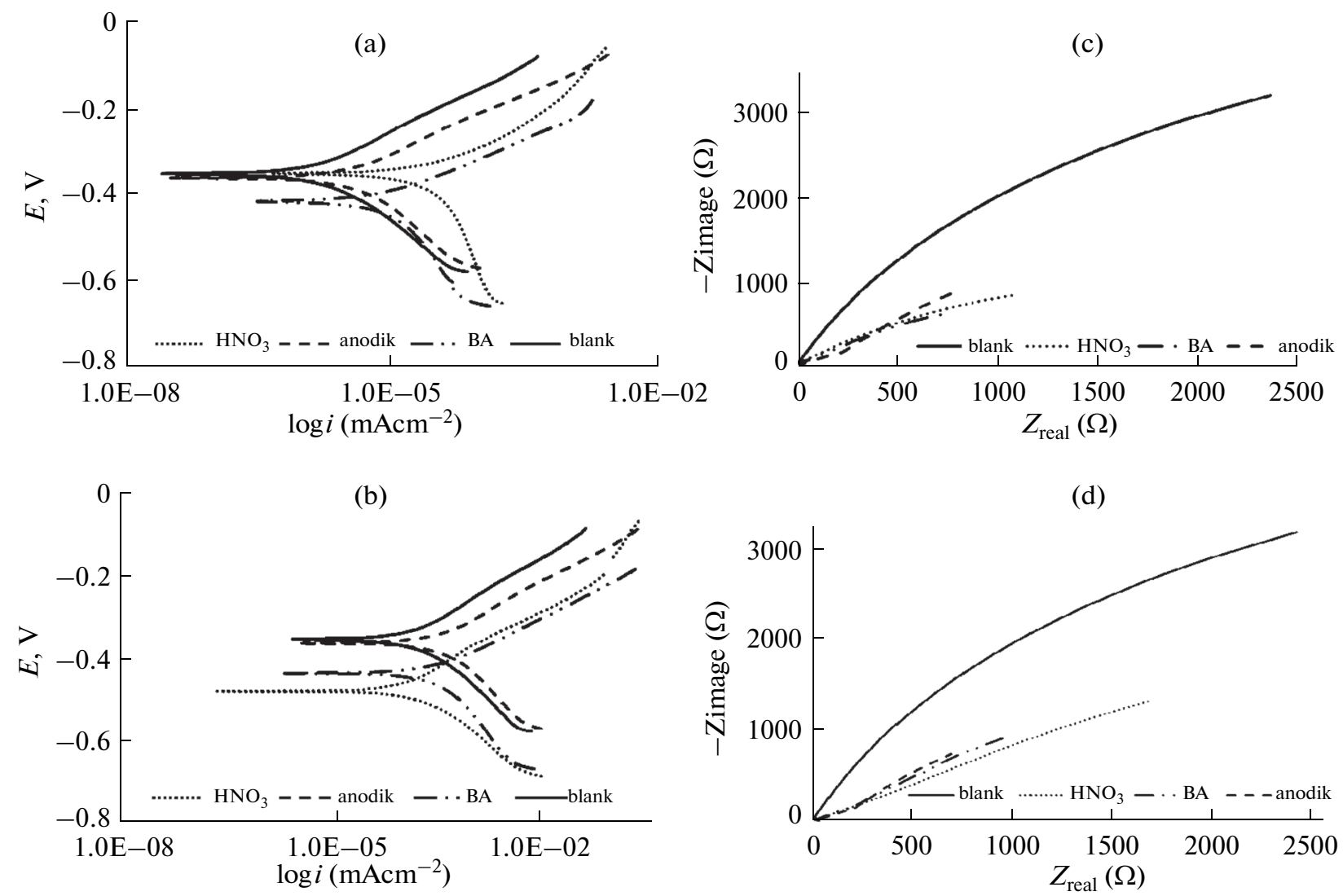

According to Kumar et al. [79] as shown in equation $1,5,6$, hydrogen formation reactions may lead hydrogen atoms that migrate from the surface to form $\mathrm{H}_{2}$ molecule. Combination of hydrogen molecules results in macroscopic bubbles in gas form. There cannot be any deposit in sites formed with HAP hydrogen bubbles, because there is not any mechanism for mass transfer which would pass through this phase. Because $\mathrm{H}_{2}$ is non-conducting. Ion migration and diffusion must be between bubble-HAP interface. Enlargement

Fig. 3. Electrochemical plots for AISI 316 L SS after electrodeposition HA coating 
Table 3. Corrosion characteristics of AISI 316L SS after electrodeposition HA coating

\begin{tabular}{|c|c|c|c|c|c|c|c|c|}
\hline & & PTSO & $-E_{\mathrm{cor}}(\mathrm{mV})$ & $\begin{array}{c}\beta_{\mathrm{a}} \times 10^{3} \\
(\mathrm{~V} / \text { decade })\end{array}$ & $\begin{array}{c}\beta_{c} \times 10^{3} \\
(V / \text { decade })\end{array}$ & $\begin{array}{c}i_{\text {cor }} \\
\left(\mu \mathrm{Acm}^{-2}\right)\end{array}$ & $\begin{array}{c}\text { Corr.rate } \\
\text { (mpy) }\end{array}$ & $\begin{array}{c}R_{p} \\
(\mathrm{k} \Omega)\end{array}$ \\
\hline \multirow[t]{2}{*}{ Uncoated } & Ringer'ssolution & - & 375 & 133 & 172 & 4.44 & 1.996 & 8.979 \\
\hline & $\% 0.9 \mathrm{NaCl}$ solution & - & 322 & 188 & 116 & 1.27 & 0.57 & 29.75 \\
\hline \multirow[t]{6}{*}{ Coated } & Ringer'ssolution & $\mathrm{HNO}_{3}$ & 444 & 184 & 120 & 2.08 & 0.93 & 17.36 \\
\hline & & anodic & 365 & 150 & 251 & 8.29 & 3.73 & 5.40 \\
\hline & & $\mathrm{BA}$ & 429 & 104 & 202 & 6.87 & 3.09 & 4.94 \\
\hline & $\% 0.9 \mathrm{NaCl}$ solution & $\mathrm{HNO}_{3}$ & 406 & 93 & 238 & 14.96 & 6.73 & 3.39 \\
\hline & & anodic & 372 & 118 & 138 & 4.79 & 2.16 & 5.97 \\
\hline & & $\mathrm{BA}$ & 418 & 113 & 255 & 11.16 & 5.03 & 3.60 \\
\hline
\end{tabular}

of HAP around the bubbles results in a capture. If this gas bubble erupts global HAP crystals continue to form.

\subsection{SEM Analyses after Electrodeposition HAP Coating}

The surfaces of the HAP coated biomaterials were investigated by SEM. SEM images of Ti, AISI 316L SS and Ti6Al4V alloy substrates are given Figs. 4-6

Figure $4 \mathrm{a}$ and $4 \mathrm{~b}$ images are structure of hydroxyapatite. Figure $4 \mathrm{c}$ is seen much more $\mathrm{TiO}_{2}$ on surface than hydroxyapatite

SEM analysis showed that the petal rose like apatite crystallites (Fig. 4a, 4b) are composed of hydroxyapatite [80]. The gel layers can initiate apatite nucleation on itself. Once apatite nucleation occurs, it spontaneously grows by taking calcium and phosphate ions from the surrounding environment. The sodium titanate hydrogel on the titanium alloy (Ti6Al4V) has become much more popular than pure titanium in orthopedic and

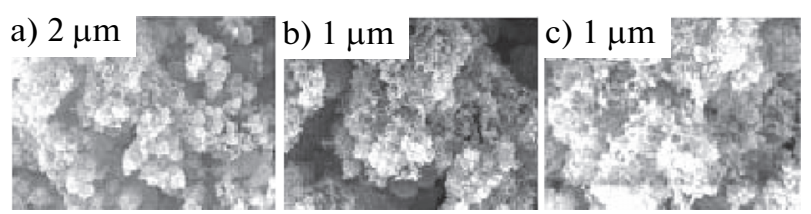

a) anodic PTSO Ti

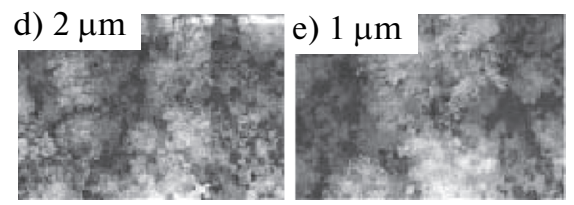

b) BA PTSO Ti

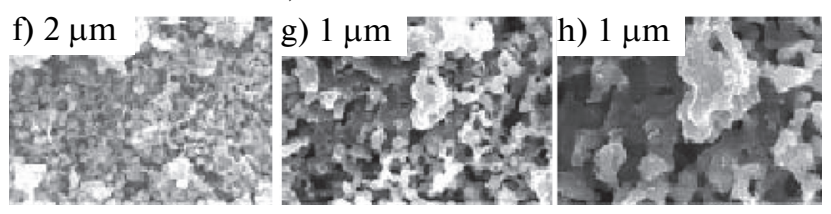

c) HNO3 PTSO Ti

Fig. 4. SEM images of Ti after electrodeposion HA coating dental applications owing to its superior mechanical properties and higher corrosion resistance [6].

Four different $\mathrm{Ca}-\mathrm{P}$ coatings are produced by electrodeposition method. These are brushite or dicalcium phosphate dihydrate (DCPD, $\left.\mathrm{CaHPO}_{4} \cdot 2 \mathrm{H}_{2} \mathrm{O}\right)$, monetit or dicalcium phosphate anhydride (DCPA, $\mathrm{CaHPO}_{4}$ ), octa calcium phosphate (OCP, $\left.\mathrm{Ca}_{8}\left(\mathrm{HPO}_{4}\right)_{2}\left(\mathrm{PO}_{4}\right)_{4} \cdot 5 \mathrm{H}_{2} \mathrm{O}\right)$ and hydroxyapatite (HAP, $\left.\mathrm{Ca}_{10}(\mathrm{OH})_{2}\left(\mathrm{PO}_{4}\right)_{6}\right)$. Forming two phase (DCPD or DCPA) are transformed HAP by using chemical methods [81]. HAP is the largest inorganic compound of natural bone.

When there are pores in HAP coating a conductive path occurs between the metallic conductor and the electrolyte. HAP coating acts as a semi conductive barrier in order to prevent interaction of substrate and the solution. Corrosion occurs due to water and chloride ion entering in the coating and ions passing through the coating. Electrochemical reactions continue in the interface of HAP and substrates. Hydroxyapatite structure in anodic PTSO AISI 316LSS' can be seen in Fig. 5a. The hydroxyapatite coatings are better in the anodic PTSO substrate.
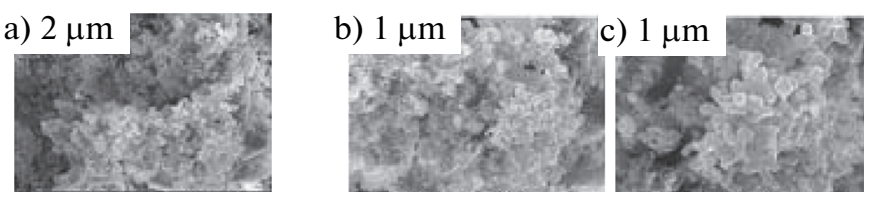

a) anodic PTSO AISI 316L SS
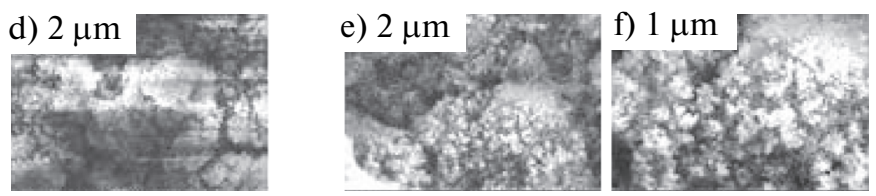

b) BA PTSO AISI 316L SS

c) HNO3 PTSO AISI 316L SS

Fig. 5. SEM images of AISI 316L SS after electrodeposition HAP coating 
In Fig. 6 hydroxyapatite structures have formed in all surface pre-treatments. This formation appears more significant in $\mathrm{HNO}_{3}$ surface pre-treated one. The negative aspects of producing electrochemical deposition coating can be given in two items:

1) Concentration of $\mathrm{OH}^{-}$ions produced with substrate cathode directly affects $\mathrm{Ca}-\mathrm{P}$ deposition. It is unknown that whether the coating formed on Ti substrate is HAP or other $\mathrm{Ca}-\mathrm{P}$ colloids.

2) Hydrogen is also produced with substrate. This causes the formation of gas bubbles. These prevent HAP from sticking to the surface. Formation of HAP should be supported by post-treating the resulting $\mathrm{Ca}-\mathrm{P}$ film with $\mathrm{NaOH}$.

Hydroxide standard reduction potential of hydrogen peroxide is $+0.68 \mathrm{~V}$ (hydrogen reference vs. electrode). Therefore addition of $\mathrm{H}_{2} \mathrm{O}_{2}$ to electrolyte solution provides an alternative electrochemical source to hydroxide ions on the cathode surface of the substrate. This supports the formation of HAP.

$$
\mathrm{H}_{2} \mathrm{O}_{2}+2 \rightarrow 2 \mathrm{OH}^{-}
$$

As a result HAP films stick better when $\mathrm{H}_{2} \mathrm{O}_{2}$ is present. It is reported that adding $\mathrm{H}_{2} \mathrm{O}_{2}$ as an addition increases the thickness and the roughness of titanium oxide film. Sticking capability and the thickness of HAP films increase with temperature. This depends on three factors.

1) Dissolubility of brushite and HAP decreases with increased temperature. Thus the particle nucleation rate will increase to form $\mathrm{Ca}-\mathrm{P}$.

2) Higher deposition temperature supports the formation of more crystallized film.

3) As the temperature gets higher less hydrogen bubbles will form. This in turn, will damage less the growth of Ca-P film that holds on to the surface of the substrate $[66,78,82,83]$.

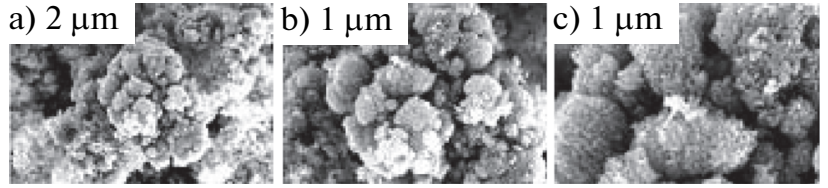

a) HNO3 PTSO Ti6AI4V

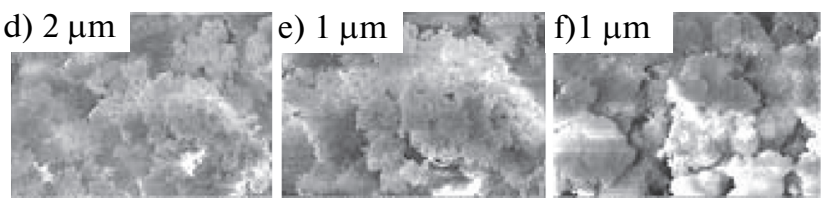

b) BA PTSO Ti6AI4V

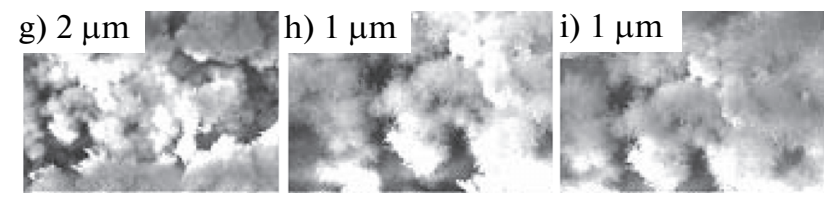

c) anodic PTSO Ti6AI4V

Fig. 6. SEM images of Ti6Al4V after electrodeposition HAP coating

\subsection{EDS Analyses after Electrodeposition HA Coating}

EDS analyses of Ti, AISI 316L SS and Ti6Al4V alloy substrates are given Figs. 7-9 EDS analysis of the coating of biomaterials shows the presence of $\mathrm{Ca}, \mathrm{P}$ and $\mathrm{O}$. Major peaks due to $\mathrm{Ca}, \mathrm{P}$ and $\mathrm{O}$ indicated that the coating composed of apatite phase [80]. It is well known that the grain boundaries may act as fast atomic diffusion channels, and various kinds of non-equilibrium structural defects can accelerate the chemical activity. These cracks were caused by the different expansion between the coating and the substrate during the heat treatment process. Such a cracked surface is beneficial to the adhesive strength between the $\mathrm{TiO}_{2}$ and HAP layers because the subsequently coated HAP gel can fill in the cracks and cover the surface of $\mathrm{TiO}_{2}$ layer completely [74].

Table 4. EDX quantitative analyses ( $\%$ atom) after electrodeposition HA coating

\begin{tabular}{|c|c|c|c|c|c|c|c|c|c|}
\hline Substrate & $\mathrm{O}$ & $\mathrm{P}$ & $\mathrm{Ca}$ & $\mathrm{Ti}$ & $\mathrm{Na}$ & $\mathrm{CI}$ & $\mathrm{Cr}$ & $\mathrm{Fe}$ & $\mathrm{Ca} / \mathrm{P}$ \\
\hline Ti (anodic PTSO) & 62.42 & 13.11 & 23.66 & - & 0.81 & - & - & - & 1.80 \\
\hline Ti (BA PTSO) & 58.07 & 11.39 & 29.92 & 0.62 & - & - & - & - & 2.63 \\
\hline $\mathrm{Ti}\left(\mathrm{HNO}_{3} \mathrm{PTSO}\right)$ & 66.22 & 3.70 & 13.88 & 16.20 & - & - & - & - & 3.75 \\
\hline 316 LSS (anodic PTSO) & 60.34 & 10.18 & 28.97 & & 0.35 & & 0.17 & & 2.84 \\
\hline 316 LSS (BA PTSO) & 63.09 & 6.86 & 30.05 & - & - & - & - & - & 4.38 \\
\hline $316 \mathrm{LSS}\left(\mathrm{HNO}_{3} \mathrm{PTSO}\right)$ & 59.01 & 12.07 & 26.89 & - & - & - & 0.83 & 1.20 & 2.23 \\
\hline Ti6Al4V(anodic PTSO) & 57.95 & 14.71 & 24.18 & 0.42 & 2.38 & 0.34 & - & - & 1.64 \\
\hline Ti6Al4V (BA PTSO) & 64.00 & 10.66 & 24.43 & 0.16 & - & 0.75 & - & - & 2.29 \\
\hline Ti6Al4V $\left(\mathrm{HNO}_{3}\right.$ PTSO $)$ & 61.38 & 12.95 & 24.79 & 0.75 & - & 0.12 & - & - & 1.91 \\
\hline
\end{tabular}

"_" not determined 

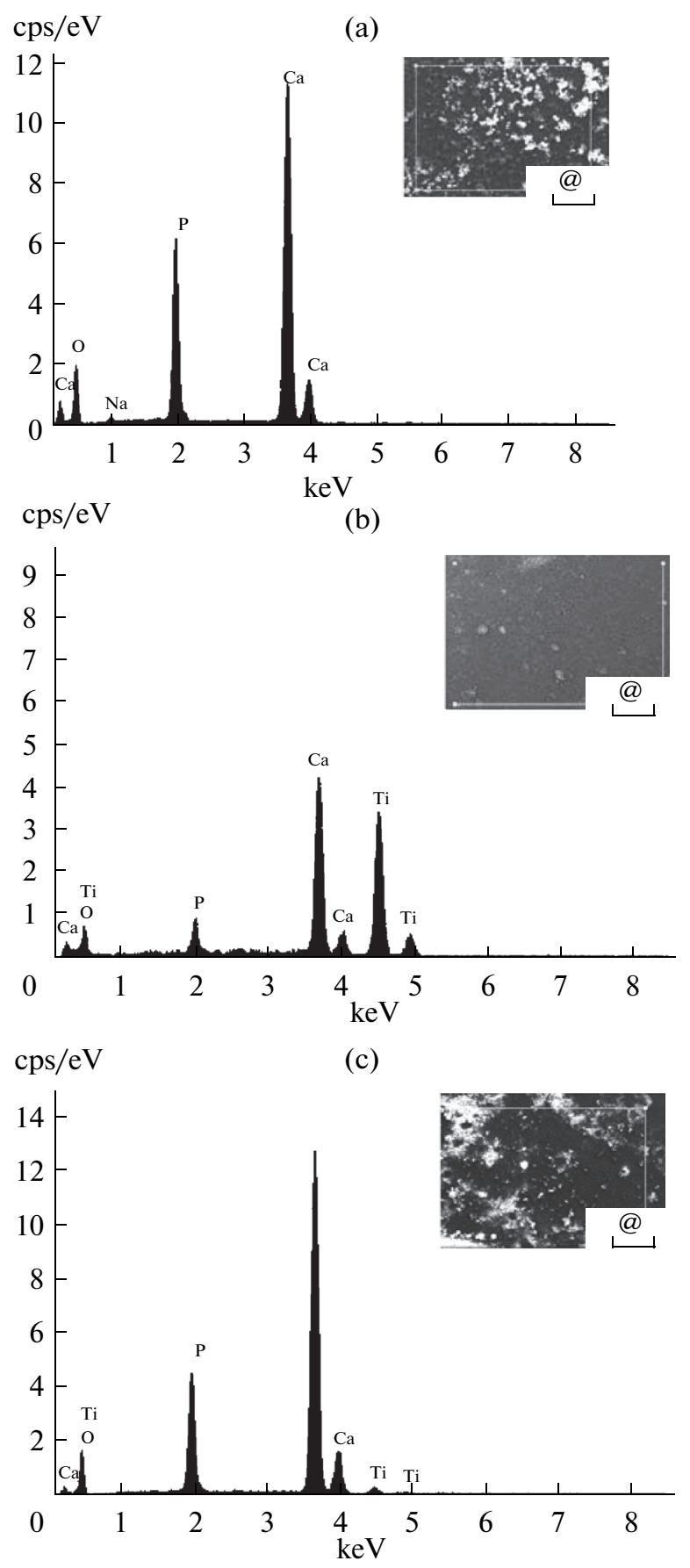

Fig. 7. EDX analysis of Ti after electrodeposition HAP coating

It is seen in Fig. 7a there are $\mathrm{Ca}, \mathrm{O}$ and $\mathrm{P}$ on the surface. This supports the formation of HAP. Presence of $\mathrm{Na}$ on the surface results from the $\mathrm{NaNO}_{3}$ present in the electrodeposition solution. In Fig. $7 \mathrm{~b}$ there are Ti peaks on the surface in addition to $\mathrm{Ca}, \mathrm{O}$ and $\mathrm{P}$. A Ti peak due to substrate is present in Fig. 7b, which indicates that the coating was not thick enough to prevent the penetration of EDS beam up to the substrate surface [80]. This shows that the surface did not close properly. There
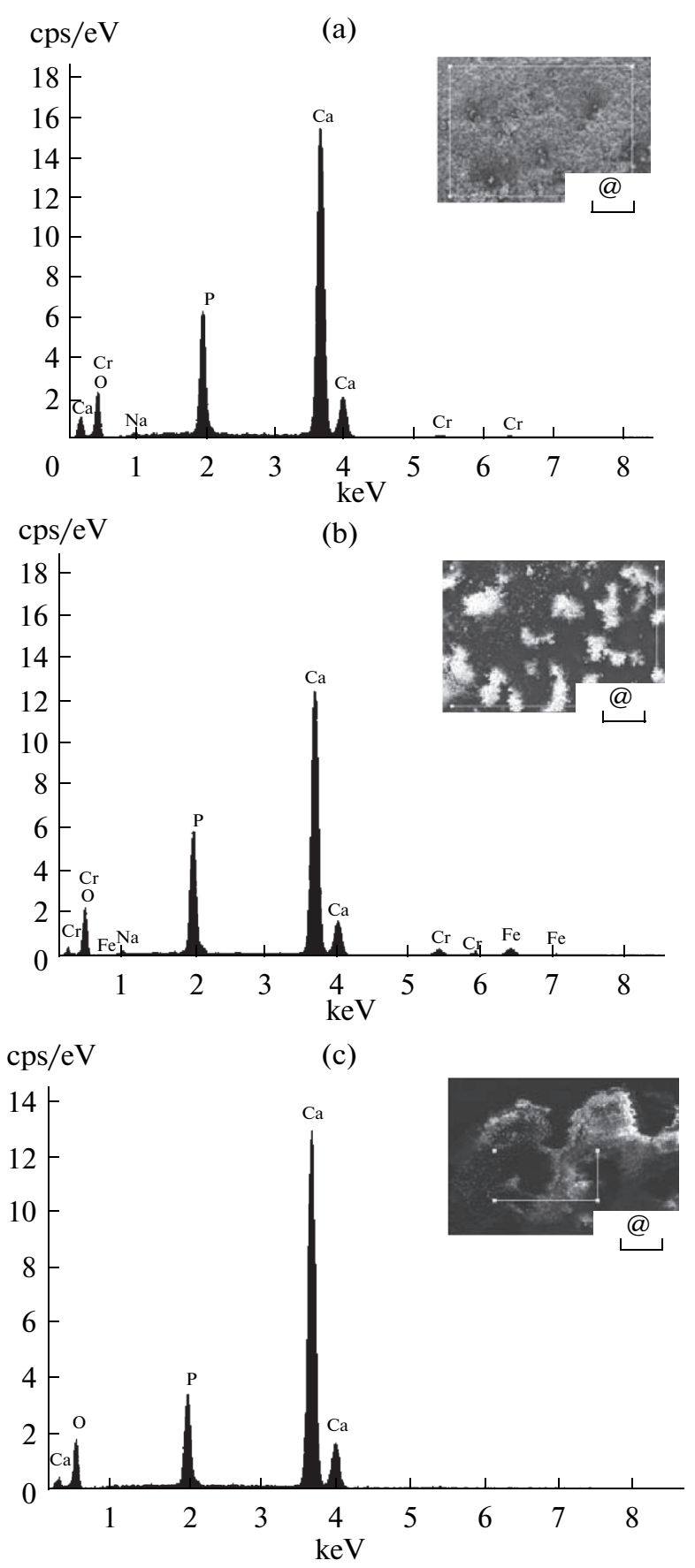

Fig. 8. EDX analysis of AISI 316L SS after electrodeposition HAP coating

are $\mathrm{Ca}, \mathrm{O}$ and $\mathrm{P}$ on the surface in Fig. 7c, Ti peak is hardly present. In Fig. 8a there is $\mathrm{Cr}$ peak on the surface of anodic surface pre-treated steel in addition to $\mathrm{Ca}, \mathrm{O}$ and $\mathrm{P}$ peaks. In Fig. $8 \mathrm{c}$ there are only $\mathrm{Ca}, \mathrm{O}$ and $\mathrm{P}$ on the surface, and hydroxyapatite has formed on the surface. In Fig. 8b though very little there are $\mathrm{Cr}$ and $\mathrm{Fe}$ peaks. In Fig. 9 there are $\mathrm{Ca}, \mathrm{O}$ and $\mathrm{P}$ peaks on the surface and in addition a small amount of $\mathrm{Ti}$ peak. Hydroxyapatite has formed on the surface. The quanti- 


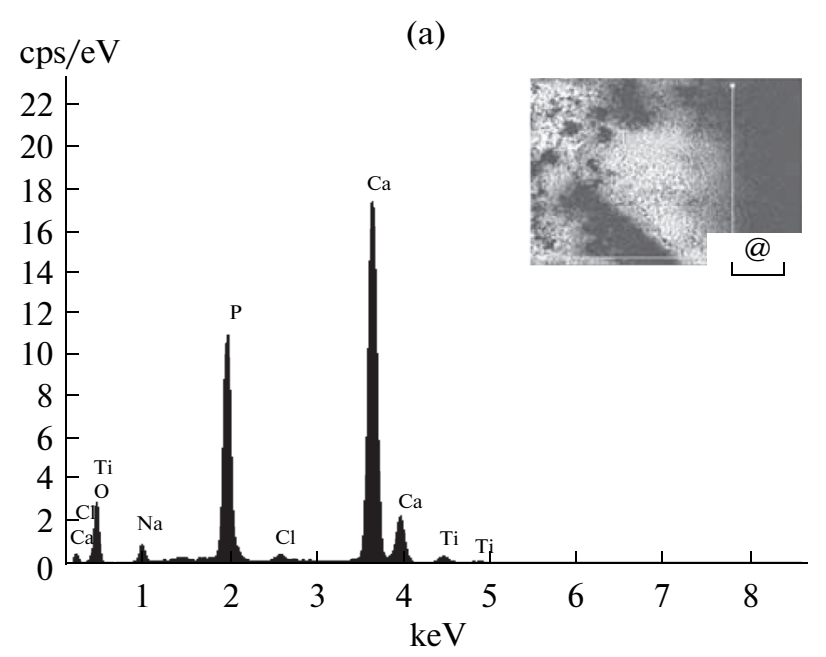

(b)
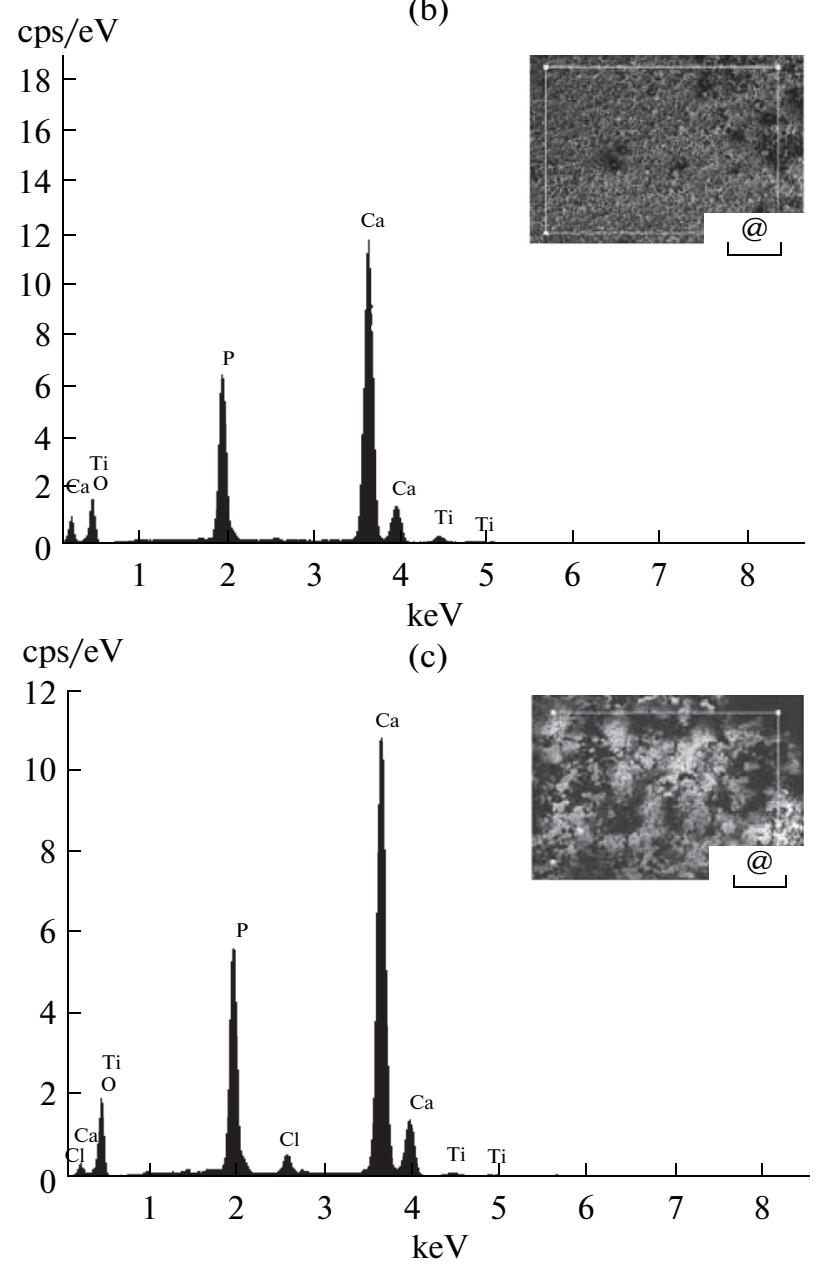

Fig. 9. EDX analysis of Ti6Al4V alloy after electrodeposition HAP coating

tative element analyses of EDS peaks between Figures $7=-9$ are given in Table 4 .

In Table 4 is seen that in general there are $\mathrm{Ca}, \mathrm{P}$ and $\mathrm{O}$ on substrate surfaces. This points out that there are

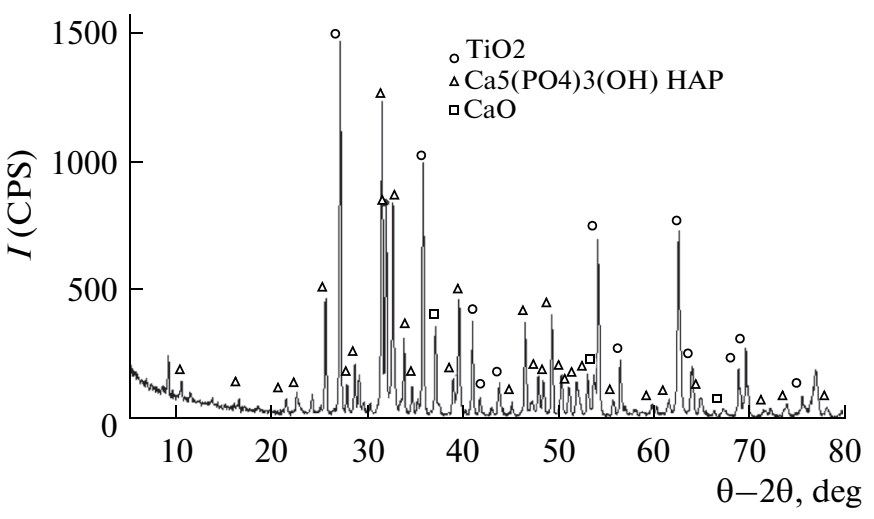

Fig. 10 XRD analysis of BA PTSO Ti after electrodeposition HAP coating

calcium phosphate coatings on substrate surfaces. $\mathrm{Ca} / \mathrm{P}$ ratios vary. The $\mathrm{Ca} / \mathrm{P}$ ratio in hydroxyapatite structure is 1.67. The closest value to this in EDX analyses is seen in anodic PTSO Ti6Al4V alloy substrate.

However, post treatment of the electrosynthesized HA coatings can lead to a variety of decomposition products such as tricalcium phosphate (TCP), tetracalcium phosphate, oxyhydroxyapatite, brushite $\left(\mathrm{CaHPO}^{4} \cdot 2 \mathrm{H}_{2} \mathrm{O}\right)$ and others. Since HA tends to decompose to TCP at temperatures around $800^{\circ} \mathrm{C}$, it is important to keep the particle sizes as small as possible to enhance sinterability and uniformity. In addition, the stoichiometry of the HA coatings has been shown to be important in these decomposition reactions. When considering the preparation of HAP coatings by electrochemical synthesis, several factors have to be considered, including solution composition, $\mathrm{pH}$ and deposition temperature. These factors affect the purity, crystallinity, stoichiometry, morphology and mechanical strength of the resulting coatings [7].

\subsection{XRD Analyses after Electrodeposition HA Coating}

XRD analyses after electrodeposition HAP coating are given Figs. 10-12.

It is analyzed that in Fig. 10 and Fig. 11 there are HAP, $\mathrm{TiO}_{2}$ and $\mathrm{CaO}$ on substrate surfaces. In Fig. 12 there are only $\mathrm{CaO}$ and HAP. It is seen that HAP has formed on the surface in all three figures.

As the sintering temperature increases the mechanical property of the coating was found to be increased. This increase in adhesive streng this a result of mechanical inter locking and chemical bonding between the coating and the underlying substrate [84]. Sintering temperature increases, the amount of TCP in the coating increases and the HA content decreases sharply. This decomposition during sintering seems to be catalyzed by the underlying metal substrate that oxidizes in air and catalyzes decomposition of HA to TCP and other components. Metal substrates reacting with the 


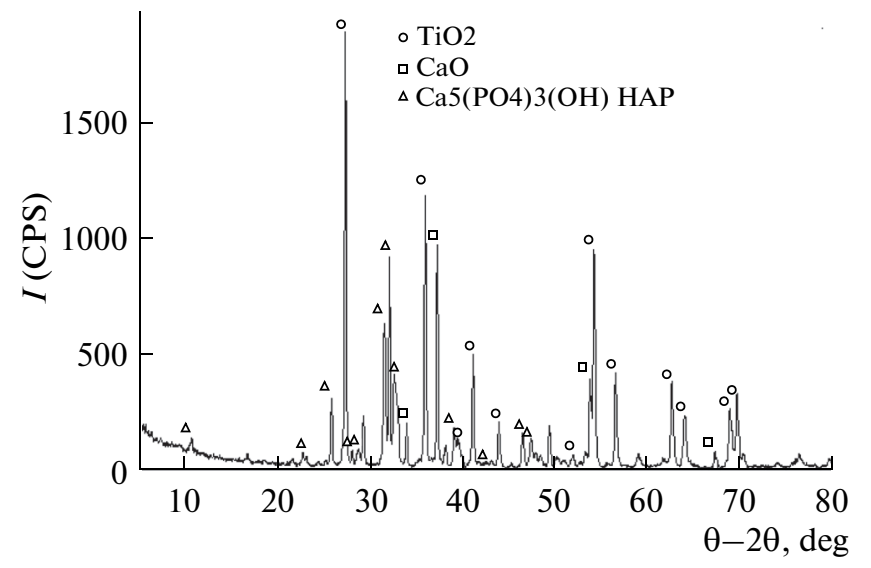

Fig. 11 XRD analysis of BA PTSO Ti6Al4V after electrodeposition HAP coating

HA coatings and inducing decomposition, especially in oxygen rich atmospheres.

\subsection{Coating Thickness Measurement Analyses}

The thickness of the HAP coatings obtained on the substrate surface as a result of electrodeposition studies were measured using EBAN $2000 \mathrm{MK} 2(0-1000 \mu \mathrm{m})$ device. Measurements have been taken from three points on the surface of each HAP coated electrode. Given values are the arithmetic averages of such measurements.

The thickness of HAP coatings produced with electrodeposition method was also measured. When surface pre-treatments of electrodes are considered among themselves the thickest HAP coatings are seen in BA PTSO samples. When Ti6Al4V is examined the coating thicknesses follow $\mathrm{HNO}_{3}<$ anodic $<$ BA order (Table 1). When $i_{\text {cor }}$ values are checked the lowest corrosion rate was measured for $\mathrm{HNO}_{3}$ PTSO Ti6Al4V substrate in Ringer solution. Where as the highest corrosion rate was measured for anodic PTSO Ti6Al4V substrates in Ringer and $0.9 \% \mathrm{NaCl}$ solutions. Electrodeposition is an electrochemical method. Anodic PTSO was performed on substrates by applying $5 \mathrm{~V}$ voltage and a thin oxide layer was formed on surfaces there of. This oxide layer may have acted as a barrier against sticking of $\mathrm{Ca}^{2+}$ and $\mathrm{P}$ on to the surface in electrodeposition coating.

When it is examined for Ti substrates (Table 2 and Table 5) HAP coating thickness of $\mathrm{HNO}_{3}$ and anodic

Table 5. Thickness of HAP coatings on formed substrates $(\mu \mathrm{m})$

\begin{tabular}{l|c|c|c}
\hline \multicolumn{1}{c|}{ PTSO } & Ti6Al4V & Ti & AISI 316L SS \\
\hline $\mathrm{HNO}_{3}$ & 46 & 34 & 180 \\
Anodic & 56 & 32 & 185 \\
BA & 72 & 80 & 192 \\
\hline
\end{tabular}

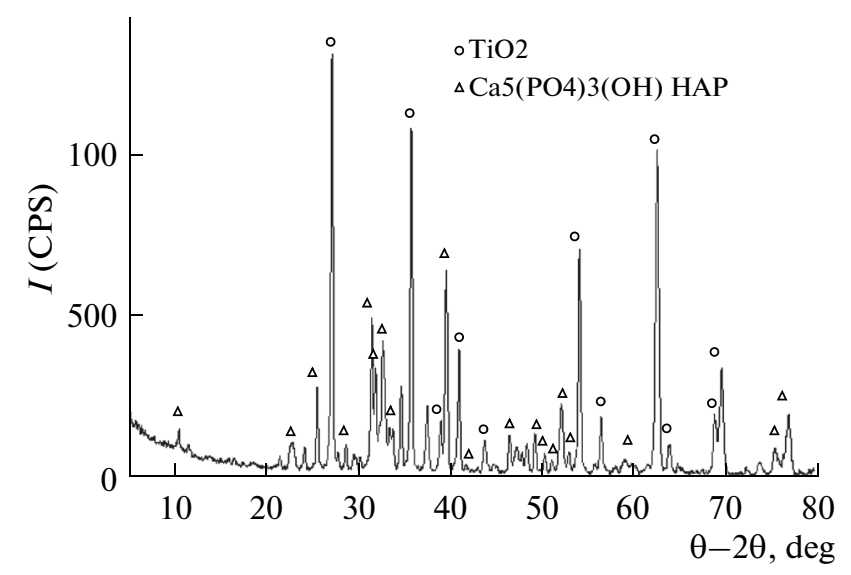

Fig. 12. XRD analysis of $\mathrm{HNO}_{3}$ PTSO Ti after electrodeposition HAP coating

PTSO substrates are very close to each other (it is $34 \mu \mathrm{m}$ for $\mathrm{HNO}_{3}$ PTSO Ti and $32 \mu \mathrm{m}$ for anodic PTSO Ti). A HAP coating thickness of $80 \mu \mathrm{m}$ was measured for BA PTSO substrate. The lowest corrosion rate in Ringer solution was found in $\mathrm{HNO}_{3}$ PTSO Ti substrate. The corrosion rate was the highest in BA PTSO Ti substrate. Since $\mathrm{HNO}_{3}$ PTSO supports oxide formation the lowest corrosion rate was determined in this surface pretreatment. The lowest corrosion rate in $0.9 \% \mathrm{NaCl}$ solution was determined in BA PTSO Ti substrate.

The thickest HAP coatings in electrodeposition method were formed on AISI 316L stainless steel (Table 5). $i_{\text {cor }}$ values of AISI $316 \mathrm{~L}$ stainless steel were determined higher when compared to pure $\mathrm{Ti}$ and Ti6Al4V substrates (Table 3 ). The lowest $i_{\text {cor }}$ value was seen in HNO3 PTSO AISI 316L SS substrate in Ringer solution. The highest $i_{\text {cor }}$ value was determined in $\mathrm{HNO}_{3}$ PTSO substrate in $0.9 \% \mathrm{NaCl}$ solution.

\section{CONCLUSIONS}

The corrosion rate of HAP coated substrates with by using electrodeposition method has increased. $E_{\text {cor }}$ values have shifted to more negative potentials within Ringer and $0.9 \% \mathrm{NaCl}$ solutions. This showed that, electrochemical deposition HAP coating could not prevent the corrosion. SEM analysis showed that the petal rose like apatite crystallites are composed of hydroxyapatite. EDS analysis of the coating of biomaterials shows the presence of $\mathrm{Ca}, \mathrm{P}$ and $\mathrm{O}$. Major peaks due to $\mathrm{Ca}, \mathrm{P}$ and $\mathrm{O}$ indicated that the coating composed of apatite phase. XRD analyses shows that HAP has formed on the substrates surfaces. When surface pretreatments of electrodes are considered among themselves the thickest HAP coatings are seen in BA PTSO samples. 


\section{ACKNOWLEDGMENTS}

The authors gratefully acknowledge the Scientific and Technical Research Council of Turkey

(TUBITAK) for financial support with the Grant Number of 107M563.

\section{REFERENCES}

1. Cui, X., Kim, H.M., Kawashita, M., et al., Nakamura Dental Materials, 2009, vol. 25, p. 80.

2. Wei, D., Zhou, Y., and Yang, C., Ceramics International, 2009, vol. 35, p. 2545.

3. Alsaran, A., Purcek, G., Hacisalihoglu, I., et al., Surface \& Coatings Technology, 2011, vol. 205, p. 537.

4. Nagarajan, S. and Rajendran, N., Appl. Surf. Sci., 2009, vol. 255 , p. 3927.

5. Gu, Y.W., Khor, K.A., and Cheang, P., Biomaterials, 2003, vol. 24, p. 1603.

6. Wang, J., Layrolle, P., Stigter, M., and Groot, K.D., Biomaterials, 2004, vol. 25, p. 583.

7. Yuan, Q. and Golden, T.D., Thin Solid Films, 2009, vol. 518, p. 55.

8. Xu, W., Hu, W., Li, M., and Wen, C., Mater. Lett., 2006, vol. 60, p. 1575 .

9. Wen, C.E., Xu, W., Hu, W.Y., and Hodgson, P.D., Acta Biomaterialia, 2007, vol. 3, p. 403.

10. Fan, X., Chen, J., Zou, J., et al., Trans. Nonferrous Mety. Soc. China, 2009, vol. 19, p. 347.

11. Kim, T.N., Feng, Q.L., Luo, Z.S., et al., Surface and Coatings Technolog., 1998, vols. 1-2, p. 20.

12. Luo, Z.S., Cui, F.Z., Feng, U.Q.L., et al., Spector Surface and Coatings Technology, 2000, vol. 131, p. 192.

13. Choi, J., Kim, H., and Lee, I., Biomaterials, 2000, vol. 21, p. 469.

14. Rabiei, A., Thomas, B., Jin, C., et al., Surface \& Coatings Technology, 2006, vol. 20, p. 6111.

15. Lee, I., Zhao, B., Lee, G., et al., Surface \& Coatings Technology, 2007, vol. 201, p. 5132.

16. Yugeswaran, S., Yoganand, C.P., Kobayashi, A., et al., Journal of the Mechanical Behavior of Biomedical Materials.

17. Sergo, V., Sbaizero, O., and Clarke, D.R., Biomaterials, 1997, vol. 18, p. 477.

18. McLeod, K., Kumar, S., Smart, R.S.C., et al., Appl. Surf. Sci., 2006, vol. 253, p. 2644.

19. d'Haese, R., Pawlowski, L., Bigan, M., et al., Surface \& Coatings Technology, 201@, vol. 204, p. 1236.

20. Cannillo, V., Pierli, F., Sampath, S., and Siligardi, C., Journal of the European Ceramic Society., 2009, vol. 29, p. 611.

21. Blind, O., Klein, L., Dailey, H.B., and Jordan, L., Dental Materials, 2005, vol. 21, p. 1017.

22. Yang, S., Xing, W., and Man, H.C., Appl. Surf. Sci., 2009, vol. 255, p. 9889.

23. Wang, C.K., Chern Lin, J.H., Ju, C.P., et al., Biomaterials, 1997, vol. 18, p. 1331.

24. Bao, Q., Chen, C., Wang, D., et al., Appl. Surf. Sci., 2005, vol. 252, p. 1538.
25. Bigi, A., Bracci, B., Cuisinier, F., et al., Biomaterials, 2005, vol. 26, p. 2381.

26. Koch, C.F., Johnson, S., Kumar, D., et al., Materials Science and Engineering C, 2007, vol. 27, p. 484.

27. Socol, G., Torricelli, P., Bracci, B., et al., Biomaterials, 2004, vol. 25, p. 2539.

28. Socol, G., Macovei, A.M., Miroiu, F., et al., Materials Science and Engineering B, 2010, vol. 169, p. 159.

29. Nelea, V., Morosanu, C., Iliescu, M., and Mihailescu, I.N., Appl. Surf. Sci., 2004, vol. 228, p. 346.

30. Hong, Z., Luan, L., Paik, S., et al., Thin Solid Films, 2007 , vol. 515 , p. 6773 .

31. Ozeki, K., Janurudin, J.M., Aoki, H., and Fukui, Y., Appl. Surf. Sci., 2007, vol. 253, p. 3397.

32. Stan, G.E., Marcov, D.A., Pasuk, I., et al., Appl. Surf. Sci., 2010, vol. 256, p. 7102.

33. Sato, M., Sambito, M.A., Aslani, A., et al., Biomaterials, 2006, vol. 27, p. 2358.

34. Kaciulis, S., Mattogno, G., Napoli, A., et al., Journal of Electron Spectroscopy and Related Phenomena, 1998, vol. 95 , p. 61.

35. Balamurugan, A., Balossier, G., Kannan, S., et al., Ceramics International, 2007, vol. 33, p. 605.

36. Bogdanoviciene, I., Beganskiene, A., Tonsuaadu, K., et al., Materials Research Bulletin,@ 2006, vol. 41, p. 1754.

37. Liu, D.M., Yang, Q., and Troczynski, T., Biomaterials, 2002, vol. 23, p. 691.

38. Metikos-Hukovic, M., Tkalcec, E., Kwokal, A., and Piljac, J., Surface and Coatings Technology, 2003, vol. 165, p. 40.

39. Stoch, A., Jastrze, W., Dlugon, E., et al., Journal of Moleculer Structure, 2005, vol. 744-747, p. 633.

40. Arnould, C., Denayer, J., Planckaert, M., et al., Colloid and Interface Sci., 2010, vol. 341, p. 75.

41. Bracci, B., Torricelli, P., Panzavolta, S., et al., Journal of Inorganic Biochemistry, 2009, vol. 103, p. 1666.

42. Faure, J., Balamurugan, A., Benhayoune, H., et al., Materials Science and Engineering C, 2009, vol. 29, p. 1252.

43. Kokubo, T., Kim, H., Himeno, T., and Nakamura, T., Biomaterials, 2005, vol. 26, p. 4366.

44. Kokubo, T., Matsushita, T., Takadama, H., and Kizuki, T., Journal of Europan Ceramic Society, 2009, vol. 29, p. 1267.

45. Kokubo, T. and Takadama, H., Biomaterials, 2006, vol. 27, p. 2907.

46. Abdel-Aal, E.A., Dietrich, D., Steinhaeuser, S., and Wielage, B., Surface \& Coatings Technology, 2008, vol. 202, p. 5895.

47. Chai, Y.C., Truscello, S., Van Bael, S., et al., Acta Biomaterialia, 2011, vol. 7, p. 2310.

48. Corni, I., Ryan, M.P., and Boccaccini, A.R., Journal of the European Ceramic Society, 2008, vol. 28, p. 1353.

49. Djosi, M.S., Miskovic-Stankovic, V.B., Kacarevic-Popovic, Z.M., et al., Colloids and Surfaces A, 2009, vol. 341, p. 110.

50. Eliaz, N., Shmueli, S., Shur, I., et al., Acta Biomaterialia, 2009 , vol. 5, p. 3178. 
51. Hu, H.B., Lin, C.J., Hu, R., and Leng, Y., Materials Science and Engineering C, 2002, vol. 20, p. 209.

52. Kar, A., Raja, K.S., and Misra, M., Surface \& Coatings Technology, 2006, vol. 201, p. 3723.

53. Lakstein, D., Kopelovitch, W., Barkay, Z., et al., Acta Biomaterialia, 2009, vol. 5, p. 2258.

54. Lin, D.Y. and Wang, X.X., Surface \& Coatings Technology, 2010, vol. 204, p. 3205.

55. Manso, M., Jimehnez, C., Morant, C., et al., Biomaterials, 2000, vol. 21, p. 1755.

56. Park, J.H., Lee, Y.K., Kim, K.M., and Kim, K.N., Surface \& Coatings Technology, 2005, vol. 195, p. 252.

57. Song, Y.W., Shan, D.Y., and Han, E.H., Mater. Lett., 2008, vol. 62, p. 3276.

58. Sun, F., Pang, X., and Zhitomirsky, I., Journal of Materials Processing Technology, 2009, vol. 209, p. 1597.

59. Wang, H., Eliaz, N., Xiang, Z., et al., Biomaterials, 2006 , vol. 27, p. 4192.

60. Wang, J., Chao, Y., Wan, Q., et al., Acta Biomaterialia, 2009, vol. 5, p. 1798.

61. Zhang, Y.Y., Tao, J., Pang, Y.C., et al., Trans. Nonferrous Met. Soc. China, 2006, vol. 16, p. 633.

62. Zhao, X., Yang, L., Zuo, Y., and Xiong, J., Product Engineering and Chemical Technology (Chinese Journal of Chemical Engineering), 2009, vol. 17, no. 4, p. 667.

63. Zhang, Q., Leng, Y., and Xin, R., Biomaterials, 2005, vol. 26, p. 2857.

64. Zhitomirsky, D., Roether, J.A., Boccaccini, A.R., and Zhitomirsky, I., Journal of Materials Processing Technology, 2009, vol. 209, p. 1853.

65. Zhitomirsky, I., Adv. Colloid and Interface Sci., 2002, vol. 97, p. 279.

66. Blackwood, D.J. and Seah, K.H.W., Materials Science and Engineering C, 2009, vol. 29, p. 1233.

67. Dos Santos, E.A., Moldovana, M.S., Jacomine, L., et al., Materials Science and Engineering B, 2010, vol. 169 , p. 138.
68. Rakngarm, A. and Mutoh, Y., Materials Science and Engineering C, 2009, vol. 29, p. 275.

69. Chen, X., Wei Zhao, Z., Chen, A., and Hong-gui, L., Trans Nonferrous Met Soc China, 2007, vol. 17, p. 617.

70. Drevet, R., Benhayoune, H., Wortham, L., et al., Materials Characterizations, 2010, vol. 61, p. 786.

71. Arnould, C., Delhalle, J., and Mekhalif, Z., Electrochim. Acta, 2008, vol. 53, p. 5632.

72. Wang, Y., Tao, J., Wang, L., et al., Trans. Nonferrous Met. Soc. China, 2008, vol. 18, p. 631.

73. Feng Xiao, X., Tian, T., Fang, R., et al., Mate. Chem. and Phys., 2007, vol. 106, p. 27.

74. Jonasova, L., Ullera, F.A.M., Helebrant, A., et al., Biomaterials, 2004, vol. 25, p. 1187.

75. Büyüksagiş $A$., Çiftçi, N., Ergün, Y., and Kayali, Y., VIII Int. Electrochemistry Meeting, Antalya: Ankara Univ. October 8-11, 2009, p. 88.

76. Büyüksagiş A. and Çiftçi, N., VIII Int. Electrochemistry Meeting, Antalya: Ankara Univ. October 8-11, 2009, p. 89.

77. Jiao, M.J. and Wang, X.X., Mater. Lett., 2009, vol. 63, p. 2286.

78. Ban, S. and Hasegawa, J., Biomaterials, 2002, vol. 23, p. 2965.

79. Kumar, M., Dasarathy, H., and Riley, C., Journal of Biomedical Materials Research, 1999, vol. 45, no. 4, p. 302.

80. Fathi, M.H. and Hanif, A., Mater. Lett., 2007, vol. 61, p. 3978.

81. Lu, X., Zhao, Z., and Leng, Y., Journal of Crystal Growth, 2005, vol. 284, p. 506.

82. Kwok, C.T., Wong, P.K., Cheng, F.T., and Man, H.C., Appl. Surf. Sci., 2009, vol. 255, p. 6736.

83. Shih, W.J., Chen, Y.H., Wang, S.H., et al., Journal of Crystal Growth, 2005, vol. 285, p. 633.

84. Vijayalakshmi Natarajan, U. and Rajeswari, S., Journal of Crystal Growth, 2008, vol. 310, p. 4601.

SPELL: 1. odontic, 2. moldm 